Prepared for the U.S. Department of Energy

under Contract DE-AC05-76RL01830

\title{
Hanford and the Tri-Cities Economy: Historical Trends 1970-2008
}

\author{
RA Fowler \\ MJ Scott
}

October 2009

Pacific Northwest

NATIONAL LABORATORY

Proudly Operated by Battelle Since 1965 


\title{
DISCLAIMER
}

This report was prepared as an account of work sponsored by an agency of the United States Government. Neither the United States Government nor any agency thereof, nor Battelle Memorial Institute, nor any of their employees, makes any warranty, express or implied, or assumes any legal liability or responsibility for the accuracy, completeness, or usefulness of any information, apparatus, product, or process disclosed, or represents that its use would not infringe privately owned rights. Reference herein to any specific commercial product, process, or service by trade name, trademark, manufacturer, or otherwise does not necessarily constitute or imply its endorsement, recommendation, or favoring by the United States Government or any agency thereof, or Battelle Memorial Institute. The views and opinions of authors expressed herein do not necessarily state or reflect those of the United States Government or any agency thereof.

\author{
PACIFIC NORTHWEST NATIONAL LABORATORY \\ operated by \\ BATTELLE \\ for the \\ UNITED STATES DEPARTMENT OF ENERGY \\ under Contract DE-AC05-76RL01830 \\ Printed in the United States of America
Available to DOE and DOE contractors from the Office of Scientific and Technical Information,
Available to the public from the National Technical Information Service, U.S. Department of Commerce, 5285 Port Royal Rd., Springfield, VA 22161 ph: (800) 553-6847 fax: $(703) 605-6900$ email: orders@ntis.fedworld.gov online ordering: http://www.ntis.gov/ordering.htm




\section{Hanford and the Tri-Cities Economy: Historical Trends 1970-2008}

RA Fowler

MJ Scott

October 2009

Prepared for

the U.S. Department of Energy

under Contract DE-AC05-76RL01830

Pacific Northwest National Laboratory

Richland, Washington 99352 


\section{Contents}

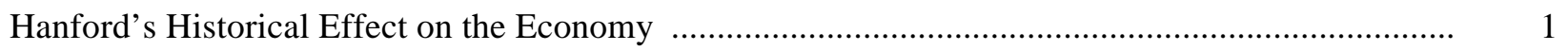

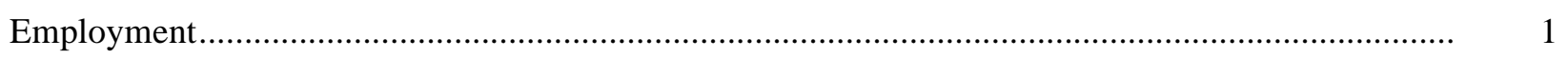

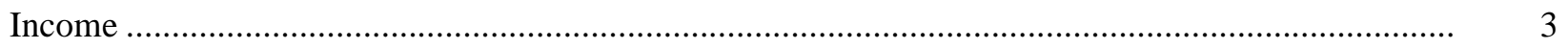

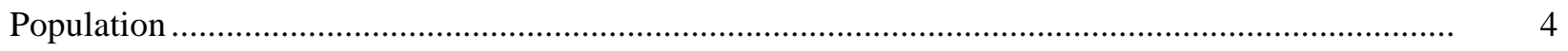

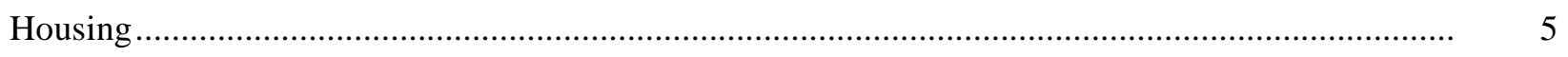

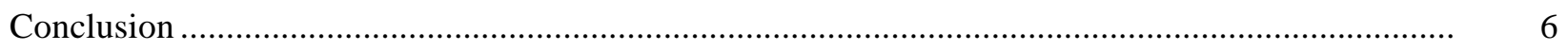

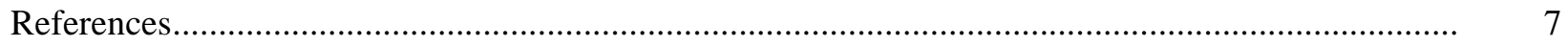

\section{Figures}

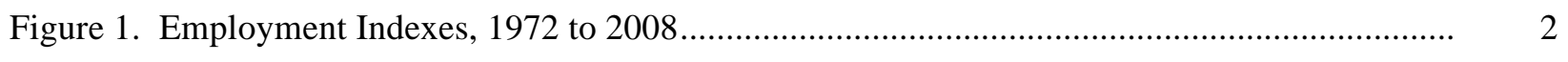

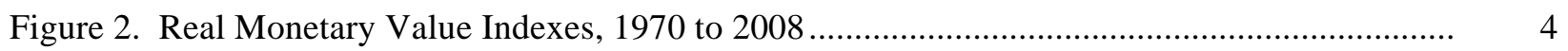

Figure 3. Employment, Population, and School Indexes, 1970 to 2008 ........................................ 5

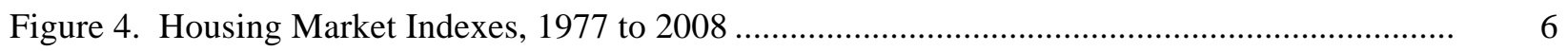




\section{Hanford's Historical Effect on the Economy}

Historically, Hanford has been the most important single entity in the Tri-Cities local economy (cities of Pasco, Kennewick, and Richland, and counties of Benton and Franklin, Washington). Census Bureau figures indicate that there were 18,360 people living in Benton and Franklin counties in 1940, before the federal government purchased the land to form the Hanford Nuclear Reservation (now known as the Hanford Site) in 1943, and by 1950 there were 64,933. After World War II ended and during the Cold War Era, Hanford expanded its operations to include research and development for peaceful uses of atomic energy. From 1947 to 1964, employment at Hanford averaged 12,500, and by 1970, the population of Benton and Franklin counties had grown to 93,356 (DOE-RL 2009 and OFM 2009).

In 1965, Hanford's research and development activities were separated from Hanford Site operations, when Battelle Memorial Institute (Battelle) began operating the newly created Pacific Northwest Laboratories (PNL) for the Atomic Energy Commission (now the Department of Energy or DOE). PNL became the Pacific Northwest National Laboratory (PNNL) in 1995. Only the term "PNNL" is used in the remainder of this paper. DOE relies on a team of contractors that work for them to carry out mission requirements at Hanford. The term "Hanford" refers to Hanford Site operations.

From 1971-1994, total area employment levels, population, and the real estate market generally mirrored Hanford contractor employment except in the late 1970s and early 1980s, when commercial nuclear power plant construction was a significant factor. This correlation has changed in recent years, as the percentage of Hanford prime contractor jobs, versus total employment in the Tri-Cities has been steadily declining. Since 1994, area employment, total income, population, and residential real estate sales and building permits have increased significantly despite very few changes in Hanford employment levels. The data indicate that recently the Tri-Cities economy has become increasingly independent of Hanford.

\section{Employment}

Since its establishment, Hanford has been the largest sources of employment in the Tri-Cities. From 1970 to 1994, the number of jobs at Hanford (which, throughout this report, does not include PNNL employment) averaged nearly $16 \%$ of the total jobs in the local economy. When Hanford began a period of downsizing in the mid-1990s, and after DOE changed the management of Hanford to a Project Hanford Management Contract that integrates a group of specialty firms under the general management of an integrating contractor, Hanford prime contractor employment fell from a peak of 14,462 in 1994 to 6,706 in 1998, and the percentage of the Hanford prime contractor jobs in the Tri-Cities fell from $16.4 \%$ to $7.4 \%$ (DOE-RL 2009 and LMEA 2009). During the transition period of the mid-1990s, some employment shifted to various subcontractors who have helped and continue to carry out mission requirements for cleaning up the Hanford Site. However, a time series of employment figures for these firms is not available. Therefore, subcontractor employment is not included in this paper. 
Early this decade, Bechtel National, Inc. (BNI) became the DOE Office of River Protection (ORP) prime contractor for designing, building and starting up a waste treatment facility for the vitrification of liquid radioactive waste. As a result, Hanford prime contractor employment grew to 8,666 in 2008 (Oliver 2009). Despite this growth, the percentage of Hanford prime contractor jobs in the Tri-Cities continues to be less than $8 \%$ of the total employment in the Tri-Cities (DOE-RL 2009).

The indexes displayed in Figure 1 illustrate how the total area employment generally mirrored Hanford employment until 1994, except for the early 1980s when the construction of Washington Public Power Supply System power plants peaked, then stopped. Since 1994, total employment in Benton and Franklin counties has risen steadily ( $30 \%$ increase), while Hanford prime contractor employment dropped dramatically then has then leveled off, averaging 7,770 since 1997, which is well below the 20-year average of 8,778 from 1970-1989 (DOE-RL 2009 and LMEA 2009).

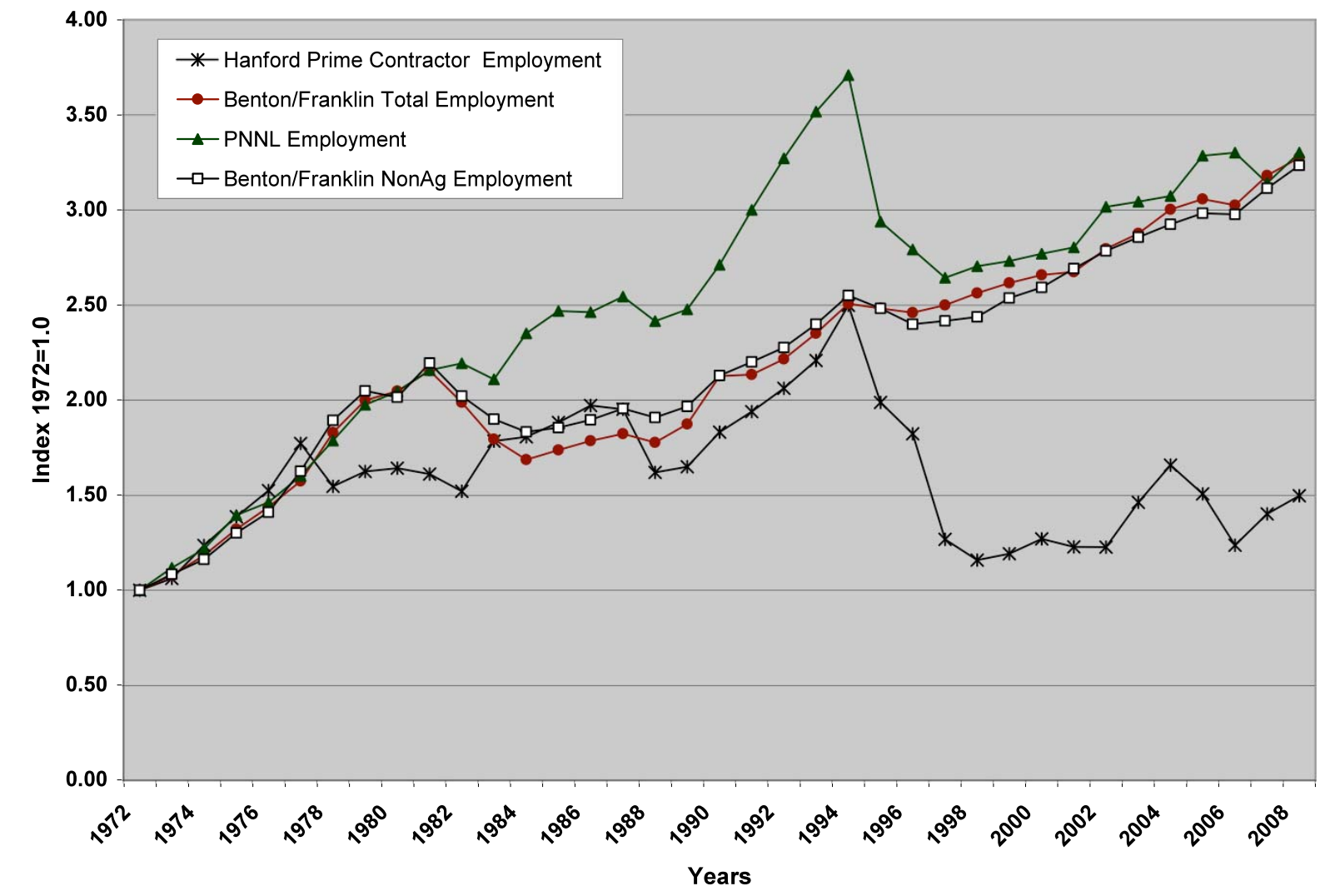

Figure 1. Employment Indexes, 1972 to 2008

The growth of the Tri-Cities economy in recent years is due in part to the success of PNNL, operated separately from Hanford by Battelle for DOE. PNNL employed 1,960 in 1965, but following a significant transfer of staff to Westinghouse in 1970-71, employment was 1,270 in 1972. Since that time, as shown in Figure 1, PNNL employment grew steadily to a peak of 4,700 in 1994. Following a period of downsizing in the mid-1990s, employment at PNNL has increased 25\% from 3,360 in 1997 to 4,195 in 2008, making it the largest single employer in the Tri-Cities (TRIDEC 2009). PNNL employment is nearing its 1994 peak, while Hanford prime contractor employment remains well below that level. Even with this growth, PNNL's role on the Hanford Site is minimal, as less than $15 \%$ of the work that PNNL performs is Hanford-related (PNNL 2009). 
Another factor in the growth of the Tri-Cities economy has been the strength of certain sectors of non-agricultural employment in Benton and Franklin counties, particularly the health care and food processing industries. Non-ag employment has increased 33\% since 1998, with the largest percentage increase coming from the health services sector at 67\% (LMEA 2009). In 2007, employment at the three major health care facilities--Kadlec Medical Center, Kennewick General Hospital, and Lourdes Health Network--totaled 2,900, up from 1,776 in 1998 (BFCOG 2007). The growth in the food processing industry this decade is evidenced by the fact that from 2000 to 2007, the number of food processing firms grew from 28 to 83, and employment increased 85.7 percent from an average of 2,140 to 3,973 (Schau 2008).

\section{Income}

Federal government funding levels at Hanford have significantly affected the local economy both through purchases of goods and services by DOE and its contractors and through spending of payroll dollars by their employees over the years. There are indications in Figure 2 that the general trend in federal budgets remains an important factor in the local economy, with recent overall Hanford budgets significantly higher in real terms than in the last year of Hanford defense production operations in 1987 (Smith 2009).

While there have been greater fluctuations in the total Hanford budget over the years than in total real personal income, changes in real personal income levels of Benton and Franklin County residents have followed the general trends of both the Hanford and PNNL budgets. Except in the early 1980s, when levels dropped slightly because nuclear power plant construction ceased, and then remained flat, total real personal income levels have grown steadily and rapidly since 1970.

Figure 2 illustrates that, when indexed relative to the U.S. Consumer Price Index (DOL 2009), the real total personal income levels of Benton and Franklin County residents and the total real Hanford fiscal year budgets have both more than tripled since 1970. Even here, however, the trend in the general economy has shown significant decoupling from Hanford, with total real personal incomes in Benton and Franklin Counties steadily growing during the Hanford downsizing period of the late 1990s. In addition, PNNL's annual business volume has nearly doubled from $\$ 488 \mathrm{M}$ in 1999 to $\$ 881 \mathrm{M}$ in 2008, and local personal income has increased 50\%, and both have shown much less volatility than the Hanford budgets (DOE-RL 2009 and PNNL 2009). 


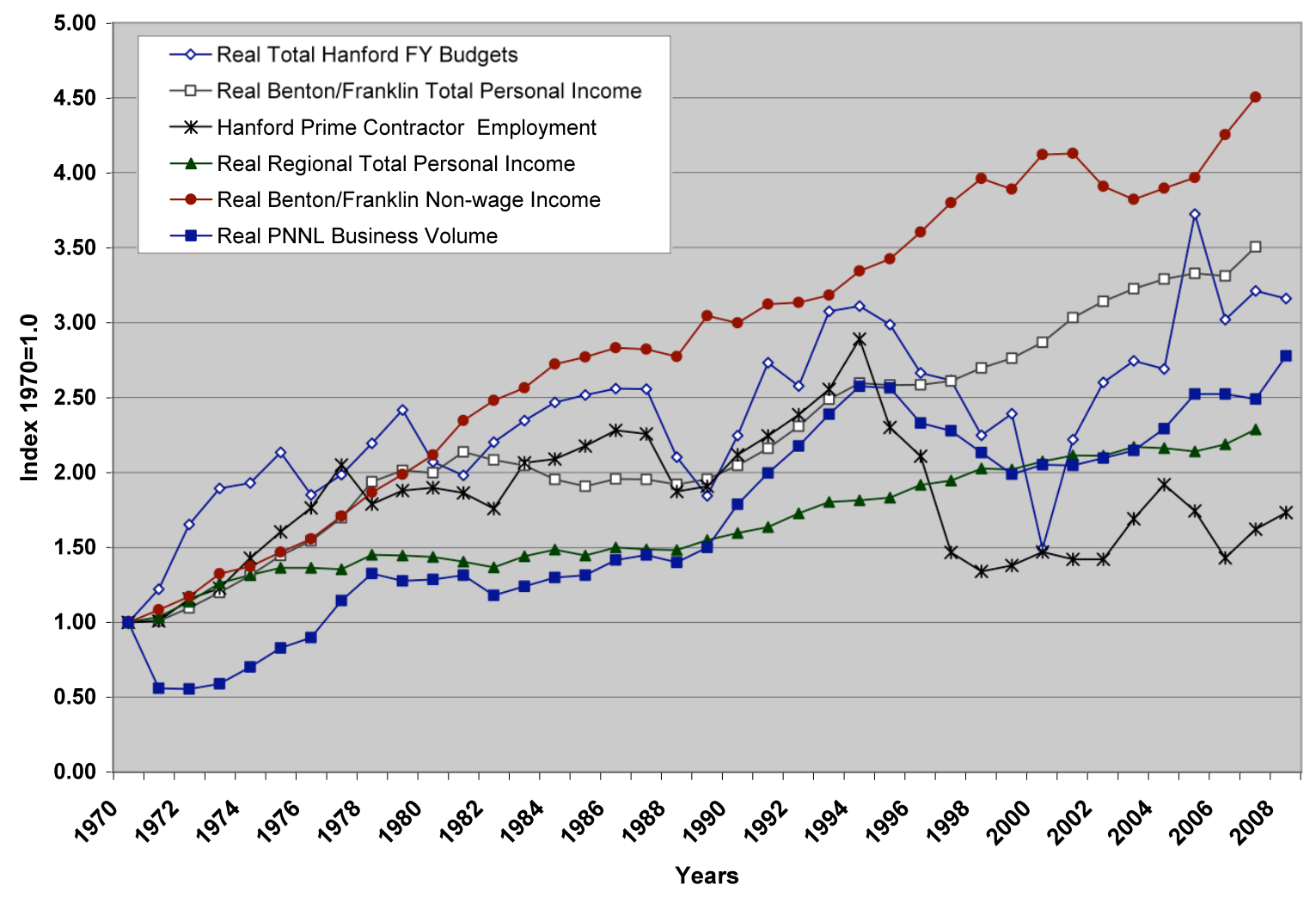

Figure 2. Real Monetary Value Indexes, 1970 to 2008

Since 1990, total personal income levels of Benton and Franklin County have risen faster than they have for the combined six surrounding counties in the region--Grant, Walla Walla, Yakima, Adams, Kittatas in Washington, and in Umatilla, Oregon. One of the contributing factors has been the increases in retirement and disability insurance and veteran's benefits (non-wage income) in Benton and Franklin counties, which have more than doubled since 1990, and make up over $10 \%$ of the total personal income in the Tri-Cities. For the most part, non-wage income has grown steadily since 1970, even during periods of decline in the Hanford budget and employment (DOC 2009).

\section{Population}

Historically, prior to 1994, changes in employment at Hanford have been one of the major drivers of change in the population of Benton and Franklin counties, which grew from 18,360 in 1940 to 93,356 in 1970. Levels for both were flat in the early 1980s then grew in the 1990s. From 1994 to 1999, however, it appears that there was a change in this relationship. Despite the loss of several thousand positions at Hanford from 1994 to 1998, the Benton and Franklin counties population grew from 169,583 to 185,652. Although total Hanford prime contractor employment has grown 18\% from 7,340 in 1997 to 8,666 in 2008, the populations of Benton and Franklin counties have increased 28\%, from 183,709 to 235,700 during this period (OFM 2009). 


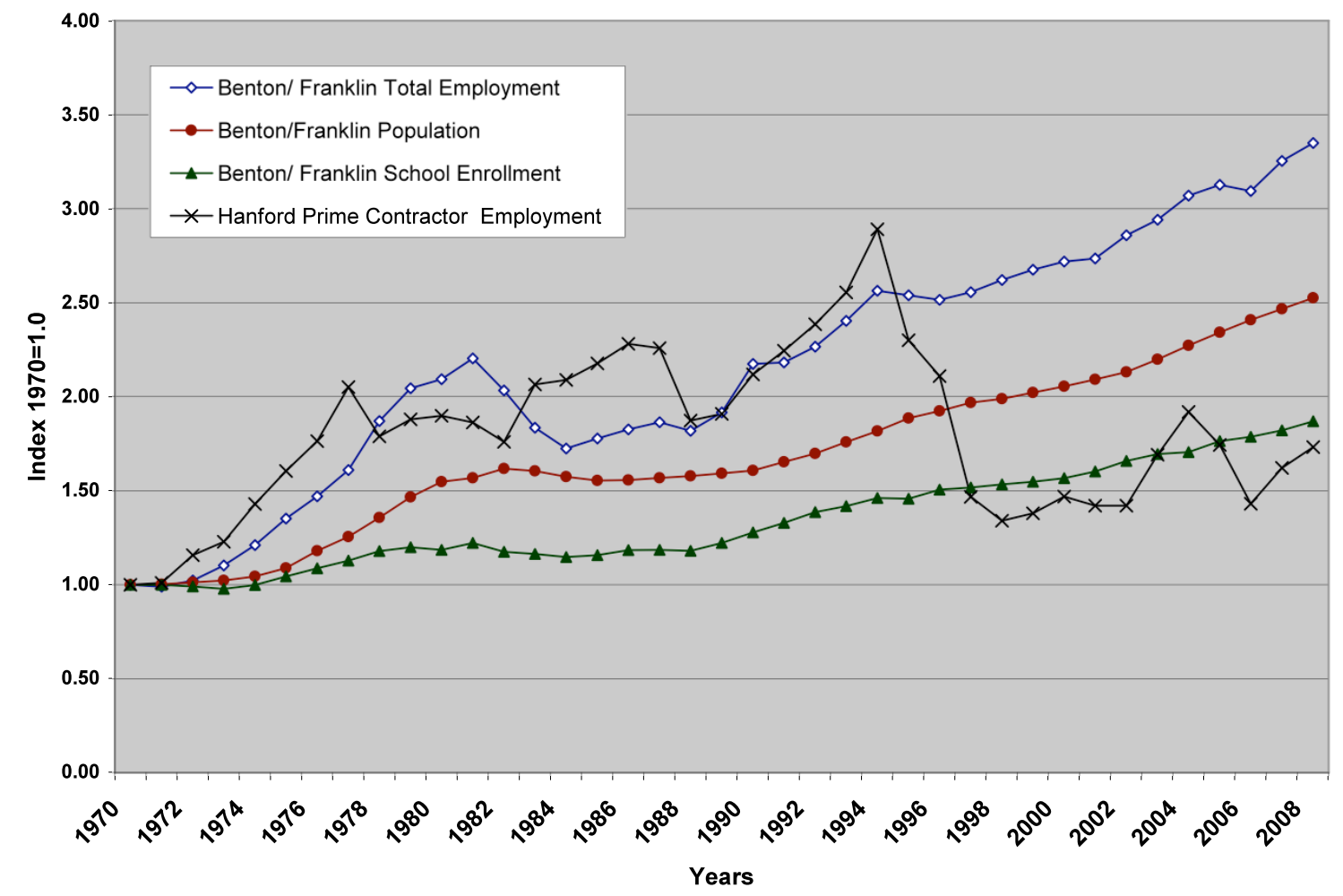

Figure 3. Employment, Population, and School Indexes, 1970 to 2008

The increase in population also is reflected in the school-age population for the 10 local public school districts in the two-county area, which have seen changes in levels that closely match the changes in population (OSPI 2009). Figure 3 illustrates the steady growth in both population and school enrollment levels, which track the upward trend of Benton and Franklin total employment and contrast with the changes in Hanford prime contractor employment since 1994, which dropped significantly in the mid 1990s and remained relatively flat until 2003.

\section{Housing}

Data from the Tri-Cities real estate market that have been collected since 1977 have generally reflected the changes in employment and government funding levels at Hanford. Figure 4 highlights these changes. The number of residential sales, single-family building permits, and housing prices followed the rise in Hanford employment in the late 1970s. The number of sales and permits dropped dramatically in the early 1980s, although that was likely due to the drop in area employment and a surplus of local housing as a result of the completion of the Washington Nuclear Power (WNP) unit number 2 (now known as the Columbia Generating Station) and the stoppage of the construction of WNP units number 1 and 4, as well as high interest rates then prevailing in the national housing market.

During the 14-year period from 1982-1995, real estate sales, permits, and prices followed Hanford employment levels and budgets, including the dramatic increases after the Hanford Site mission was changed to environmental cleanup and restoration and the Tri-Party Agreement was signed in 1989, the dramatic decreases following contractor downsizing in 1995, and the management change to the Project Hanford Management Contract in 1996. 


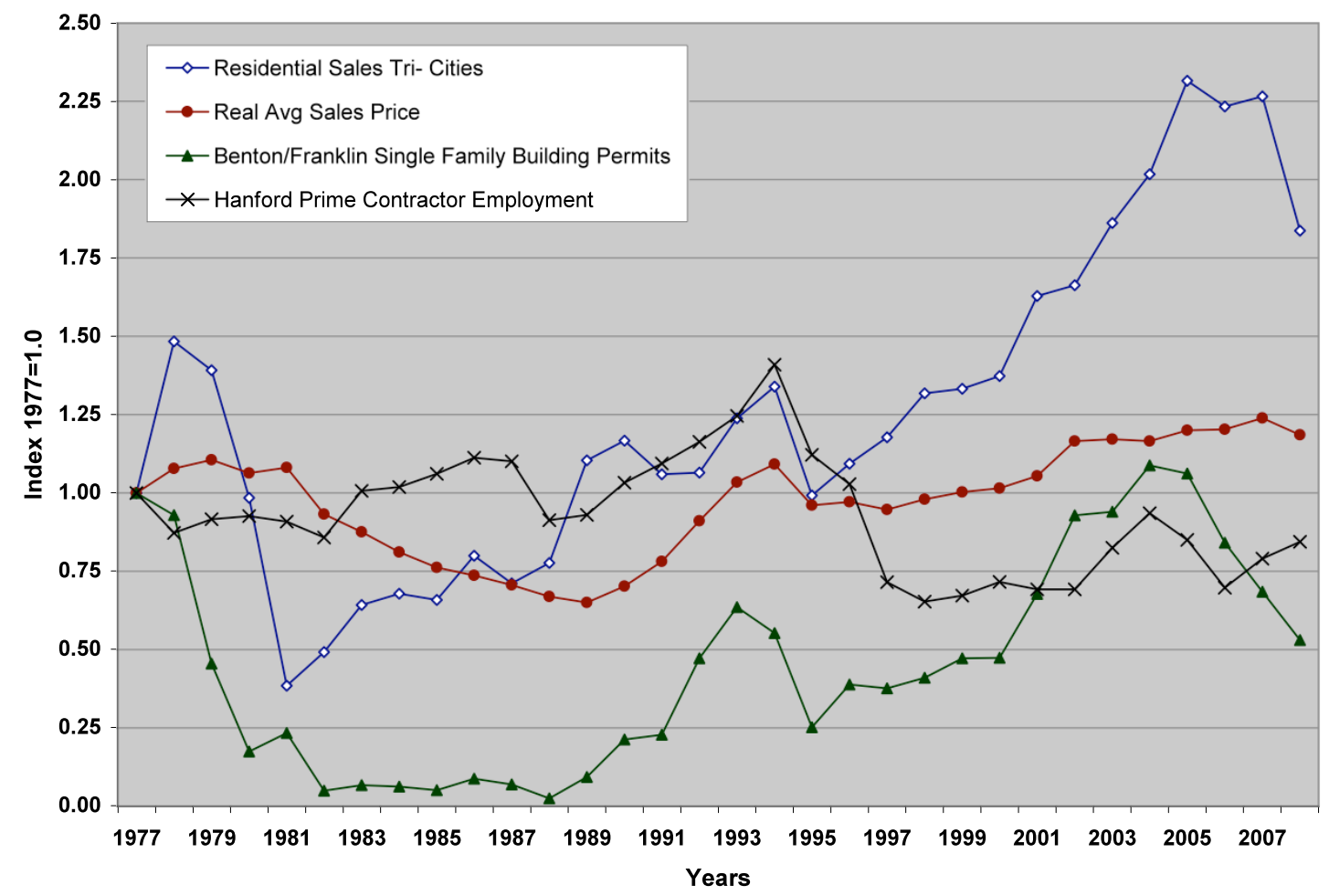

Figure 4. Housing Market Indexes, 1977 to 2008

However, in the 10-year period from 1996 to 2005, the housing market also appears to have decoupled to some extent from its former dependence on activity at Hanford. The housing market increased substantially, while Hanford prime contractor employment remained relatively flat and Hanford's budgets averaged near the levels of the mid-1990s. The number of residential sales grew $92 \%$, from 1,922 to 3,698; housing prices increased 69\%, from $\$ 112,900$ to $\$ 190,800$; and the number of single-family building permits grew $188 \%$, from 768 to 2217 at its peak in 2005 (WCRER 2009). The number of permits decreased in 2006 and 2007, and sales decreased in 2008, but this may be a reflection of the nationwide construction slump. When indexed relative to the Consumer Price Index, the real average sales price of homes in the Tri-Cities has been moderate since 1995, and prices are near the same levels that they were in the late 1970s (TCAR 2009).

\section{Conclusion}

Hanford continues to be the most important entity in the Tri-Cities economy; however, its relative impact has decreased over the last decade, showing an increasing decoupling of the general local economy from Hanford. The success of PNNL, growth in the health care and food processing industries, and increases in non-wage incomes in Benton and Franklin counties have all contributed to significant increases in the total area employment, total personal income, population levels, school enrollment, and housing permits and sales in the Tri-Cities. These indicators illustrate the degree to which the Tri-Cities economy has become independent of Hanford. 


\section{References}

Avery, LD. 2009. "Historical PNNL Sales Data.” Email message from Lori Avery (Pacific Northwest National Laboratory, Financial Performance Reporting Department) to Richard Fowler (Pacific Northwest National

Laboratory, Energy and Environment Directorate), September 1, 2009, Richland, Washington.

Benton Franklin Council of Governments (BFCOG). 2007. 2007 Major Employers Report. Benton Franklin Council of Governments, Richland, Washington. Accessed at http://www.bfcog.us/transportation.html.

Office of Financial Management (OFM). 2009. Historical/Current Data Set: Total Resident Population by Year by County, Washington 1960 to 2009. Office of Financial Management, Forecasting Division, Olympia, Washington. Accessed September 9, 2009 at http://www.ofm.wa.gov/pop/coseries/default.asp.

Office of Superintendent of Public Instruction (OSPI). 2009. Public School Enrollment Summary (Report P105Aby county). Office of Superintendent of Public Instruction, Olympia, Washington. Accessed September 9, 2009 at http://www.k12.wa.us/dataadmin/.

Oliver, CL , "Data Request - Hanford Site Employment," Email message from Cindy Oliver (DOE-RL Office of Administration) to Richard Fowler (Pacific Northwest National Laboratory, Energy and Environment Directorate), April 9, 2009, Richland, Washington.

Schau, D. 2008. Will the Real Tri-Cities Please Stand Up? Washington State Labor Market and Economic Analysis. Olympia, Washington. Accessed at

http://www.workforceexplorer.com/article.asp?articleId=9008\&PAGEID=\&SUBID=.

Smith, K, , "Hanford Budget History Data Request," Email message from Kathy Andrews-Smith (DOE-RL Financial Management Division) to Richard Fowler (Pacific Northwest National Laboratory, Energy and Environment Directorate), April 21, 2009, Richland, Washington.

Tri-City Association of REALTORS (TCAR). 2009. Tri-City Area Housing Statistics. Tri-City Association of REALTORS, Kennewick, Washington. Accessed September 9, 2009 at http://www.tricityrealtors.com/. .

Tri-City Development Council (TRIDEC). 2009. Tri-Cities, Washington Fact Sheet.. Tri-City Development Council, Kenenwick, WA. Accessed September 9, 2009 at

http://www.tridec.org/ftphome/September\%202008\%20Facts908final.pdf.

U.S. Department of Commerce (DOC). 2009. Regional Economic Information System (REIS). Bureau of Economic Analysis, U.S. Department of Commerce, Washington, D.C. Accessed September 9, 2009 at :

http://www.bea.gov/regional/docs/footnotes.cfm?tablename=CA05.

U.S. Department of Labor (DOL). 2009. Consumer Price Index History Table. Bureau of Labor Statistics, U.S. Department of Labor, Washington, D.C. Accessed September 9, 2009 at http://www.bls.gov/CPI/.

Washington Center for Real Estate Research (WCRER). 2009. Washington State Housing Market. Washington State University, Pulman, Washington. Accessed September 9, 2009 at

http://www.cbe.wsu.edu/ wcrer/market/HousingMarket.asp.

Washington State Labor Market and Economic Analysis (LMEA). 2009. Nonagricultural Wage and Salary Workers Employed in the Richland-Kennewick-Pasco MSA. and Resident Civilian Labor Force and Employment. Olympia, Washington. Accessed September 9, 2009 at http://www.workforceexplorer.com/. 


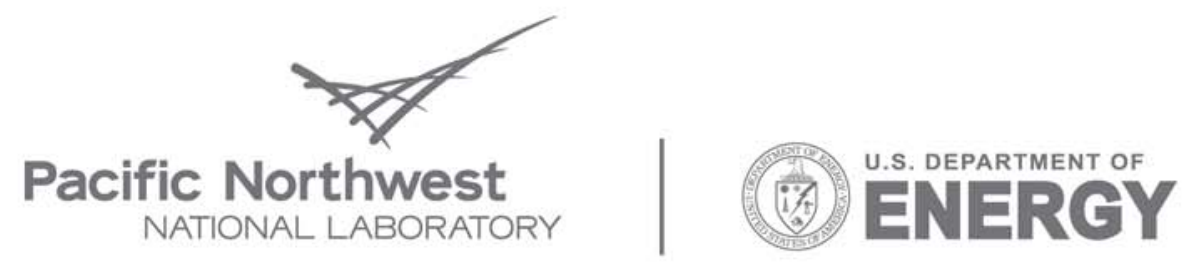

Proudly Operated by Battelle Since 1965

902 Battelle Boulevard

P.O. Box 999

Richland, WA 99352

1-888-375-PNNL (7665)

www.pnl.gov 